\title{
EVALUASI PENYUSUNAN INDIKATOR KINERJA PEMERINTAH KABUPATEN BULELENG
}

\author{
Kadek Riasmini, Ketut Desi Megayanti, Gede Riko Bayuna, Wayan Samiasa
}

Jurusan Akuntansi, Universitas Pendidikan Ganesha, Singaraja, Bali, Indonesia

\begin{abstract}
Abstrak
Penelitian ini bertujuan untuk menginvestigasi apakah indikator kinerja dalam sistem pengukuran kinerja Pemerintah Kabupaten Buleleng telah menunjukkan kesesuaian informasi atau hungan yang logis dari perencanaan strategis hingga pelaporan kinerja, bagaimana indikator kinerja pada program/kegitan SKPD dapat menunjukkan indikator kinerja berbasis hasil (result-based performance indicator) yang mendukung pencapaian kinerja Pemrintah Kabupaten Buleleng, serta bagaimana model performance blueprint dengan pendekatan OPM\&M dapat digunakan untuk mengevaluasi atas indikator kinerja Pemerintah Kabupaten Bueleng. Hasil penelitian menunjukkan bahwa indikator kinerja Pemerintah Kabupaten Buleleng belum menunjukan kesesuaian informasi mulai dari dokumen perencanaan hingga dokumen pelaporan masih banyak terdapat hal yang berbeda bahkan sulit untuk dibandingkan. Demikian pula, indikator kinerja SKPD /unit kerja belum sepenuhnya mendukung kinerja Pemerintah Kabupaten Buleleng. Hal ini ditunjukan dengan masih ditemukannya ketidakselarasan antara indikator kinerja SKPD dengan indikator kinerja sasaran Pemerintah Kabupaten Buleleng.
\end{abstract}

Kata kunci: indikator kinerja; pemerintah Kabupaten Buleleng; Model Logika

\section{Abstract}

This study aims to investigate whether the performance indicators in the performance measurement system of the Buleleng Regency Government have shown the suitability of information or logical relationships from strategic planning to performance reporting, how performance indicators in the SKPD program / activity can show results-based performance indicators (result-based performance indicators ) which supports the achievement of the performance of the Government of the Regency of Buleleng, as well as how the blueprint performance model with the OPM \& $M$ approach can be used to evaluate the performance indicators of the District Government of Bueleng. The results showed that the performance indicators of the Buleleng Regency Government have not shown the suitability of information ranging from planning documents to reporting documents, there are still many different things that are even difficult to compare. Likewise, the SKPD / work unit performance indicators do not fully support the performance of the Government of the Regency of Buleleng. This is indicated by the finding of inconsistencies between the SKPD performance indicators and the performance indicators of the Buleleng Regency Government target.

Keywords: performance indicators; Buleleng Regency government; Logic Model

\section{Pendahuluan}

Organisasi sektor publik tidak pernah luput dari kritikan masyarakat yang timbul karena ketikpuasan terhadap kinerja organisasi tersebut. Kepercayaan masyarakat semakin menurun karena banyaknya kasus yang menimpa oknum-oknum tertentu dalam organisasi pemerintah dan lambatnya pelayanan yang diberikan kepada masyrakat. Untuk memulihkan kembali kepercayaan masyarakat dan menjauhkan dari berbagai kritikan maka haruslah ada gebrakan baru oleh pemerintah yang dapat merubah pandangan masyarkat dan dapat mewujudkan Good Governance.

United Nations Development Program mendefinisikan Good Governance sebagai penyelenggaraan kekuasaan bidang politik, ekonomi dan administrative dalam mengatur berbagai masalah Negara dan juga sebagai instrument kewenangan Negara untuk mewujudkan kesejahteraan masyarakat. Tujuan utama dari Good Governance adalah mewujudkan kesejahteraan masyarakat yang berarti telah terpenuhinya berbagai macam 
kebutuhan masyarakat. Hal ini sejalan dengan kemunculan konsep baru dalam dunia manajemen yaitu New Public Management.

New Public Management merupakan sistem administrasi berbasis kinerja yang pertama dikembangkan diwilayah Anglo-Amerika Serikat pada tahun 1980an. Konsep ini memberikan perubahan yang cukup signifikan, adanya gerakan global ini yang bermula di Negara maju di Eropa kini mulai diterapkan di Negara berkembang termasuk Indonesia. Perubahan yang terlihat dari Public Management menuju New Public Management adalah manajemen professional di sektor publik, penekanan terhadap pengendalian output dan outcome, pemecahan unit-unit kerja disektor publik, menciptakan persaingan di sektor publik, mengadopsi gaya manajemen sektor privat ke sektor publik, serta disiplin dan penghematan penggunaan sumber daya.

Adanya konsep ini telah merubah sistem manajemen yang kaku, birokratis dan hierarkis menjadi model manajemen sektor publik yang lebih mengakomodir pasar. Penerapan konsep NPM dapat dipandang sebagai suatu bentuk modernisasi atau reformasi manajemen dan administrasi publik, depolitisasi kekuasaan, atau desentralisasi wewenang yang mendorong demokrasi. Perubahan tersebut telah mengubah peran pemerintah terutama dalam hal hubungan antara pemerintah dengan masyarakat (Hughes,1998).

Berbagai perubahan dalam sektor publik dapat dinilai dengan pengukuran kinerja. Menurut Mardiasmo (2002) sistem pengukuran kinerja sektor publik adalah suatu sistem yang bertujuan untuk membantu manajer sektor publik menilai pencapaian suatu strategi melalui alat ukur finansial dan nonfinansial. Hasil pengukuran kinerja tersebut harus dilaporkan dalam bentuk laporan pertanggungjawaban kinerja sebagai manifestasi telah dilakukannya akuntabilitas pubik yang berbasis hasil.

Kemunculan berbagai peraturan yang menunjukkan adanya upaya pemerintah dalam memperbaiki sistem pemerintahan untuk mewujudkan akuntabilitas dan tata kelola kepemerintahan yang baik (good governance) antara lain Instruksi Presiden Nomor 7 Tahun 1999 tentang Akuntabilitas Kinerja Instansi Pemerintah (AKIP), UU No.32 Tahun 2004 tentang Pemerintahan Daerah, UU No.33 Tahun 2004 tentang Perimbangan Keuangan antara Pemerintah Pusat dan Pemerintah Daerah, PP No 8 Tahun 2006 tentang Pelaporan Keuangan dan Kinerja Instansi Pemerintah serta Peraturan Presiden No.29 Tahun 2014 tentang Sistem Akuntabilitas Kinerja Instansi Pemerintah (SAKIP).

Dalam PERPRES tersebut kemudian dijelaskan bahwa sistem akuntabilitas kinerja instansi pemerintah adalah rangkaian sistematik dari berbagai aktivitas, alat dan prosedur yang dirancang untuk tujuan penetapan dan pengukuran, pengumpulam data, pengklasifikasian, pengikhtisaran dan pelaporan kinerja pada instansi pemerintah dalam rangka pertanggungjawaban dan peningkatan kinerja instansi pemerintah. Pelaksanaan sistem akuntabilitas kinerja akan dilaporkan dalam bentuk Laporan Akuntabilitas Kinerja Instansi Pemerintah (LAKIP) pada setiap tahunnya.

Hasil evaluasi yang di lakukan oleh kementerian Pendayagunaan Aparatur Negara dan Reformasi Birokrasi di tahun 2015 menunjukkan; Pemerintah Kabupaten Buleleng memperoleh predikat CC yang berarti memadai atau cukup baik. Namun dalam kenyataannya penyusunan laporan kinerja itu disebabkan oleh peraturan yang menuntut instansi pemerintah untuk membuatnya bukan karena kesadaran akan pentingnya laporan tersebut bagi pemerintah. Capaian indikator belum menunjukkan indikator outcome yang terukur dan berorientasi hasil.

Penelitian ini akan mencoba melihat lebih jauh mengenai indikator kinerja pada Pemerintah Kabupaten Buleleng dan SKPD terpilih berdasarkan pendekatan Ongoing Performance Measurement and Management (OPM\&M) yang merupakan pendekatan evaluasi dan perencanaan yang komprehensif dengan menggunakan model logika inovatif dan perluasan, yang dikenal dengan nama Performance Blueprint.

Sesuai dengan Inpres Nomor 7 Tahun 1999 dan peraturan pendukung lainnya, bahwa pemerintah daerah termasuk didalamnya Pemerintah Kabupaten Buleleng telah melaksanakan sistem akuntabilitas kinerja instansi pemerintah. Namun setelah adanya evaluasi laporan akuntabilitas kinerja instansi pemerintah yang dilakukan oleh Kementrian PAN dan RB menunjukkan bahwa LAKIP Pemerintah Daerah belum dapat menggambarkan 
pengukuran kinerja yang berorientasi pada hasil melainkn hanya untuk memenuhi ketentuan peraturan yang telah ditetapkan.

Adapun permasalahan yang dapat dirumuskan yaitu apakah indikator kinerja dalam sistem pengukuran kinerja Pemerintah Kabupaten Buleleng telah menunjukkan kesesuaian informasi atau hungan yang logis dari perencanaan strategis hingga pelaporan kinerja, bagaimana indikator kinerja pada program/kegitan SKPD dapat menunjukkan indikator kinerja berbasis hasil (result-based performance indicator) yang mendukung pencapaian kinerja Pemrintah Kabupaten Buleleng, serta bagaimana model performance blueprint dengan pendekatan OPM\&M dapat digunakan untuk mengevaluasi atas indikator kinerja Pemerintah Kabupaten Bueleng.

\section{Hasil dan Pembahasan}

\subsection{Kesesuaian Indikator Kinerja Pemerintah Kabupaten Buleleng}

Pemerintah Kabupaten Buleleng telah merencanakan pencapaian visi dan misi pembangunan daerah melalui tujuan dan sasaran yang tertuang dalam RPJMD Kabupaten Buleleng. Dalam RPJMD 2012-2017 pemerintah kabupaten buleleng memiliki visi yaitu : Terwujudnya Masyarakat Buleleng yang Mandiri, Sejahtera, Damai, dan Berlandaskan Tri Hita Karana. Juga memiliki 7 misi dan 21 sasaran.

\begin{tabular}{|c|c|c|c|c|}
\hline No & Misi & & Sasaran & Jumlah indikator sasaran \\
\hline \multirow[t]{3}{*}{1} & Misi \#1 & & Sasaran \#1 & Tidak disaiikan \\
\hline & & & Sasaran \#2 & Tidak disaiikan \\
\hline & & & Sasaran \#3 & Tidak disajikan \\
\hline \multirow[t]{3}{*}{2} & Misi \#2 & & Sasaran \#4 & Tidak disajikan \\
\hline & & & Sasaran \#5 & Tidak disajikan \\
\hline & & & Sasaran \#6 & Tidak disajikan \\
\hline \multirow[t]{4}{*}{3} & Misi \#3 & & Sasaran \#7 & Tidak disajikan \\
\hline & & & Sasaran \#8 & Tidak disajikan \\
\hline & & & Sasaran \#9 & Tidak disajikan \\
\hline & & 140 & Sasaran & Tidak disajikan \\
\hline \multirow{5}{*}{4} & Misi \#4 & & Sasaran & Tidak disaiikan \\
\hline & & \#11 & & \\
\hline & & & Sasaran & Tidak disajikan \\
\hline & & \#12 & & \\
\hline & & \#13 & Sasaran & Tidak disajikan \\
\hline \multirow[t]{3}{*}{5} & Misi \#5 & & Sasaran & Tidak disajikan \\
\hline & & \#14 & Socoran & Tidak dicoïkan \\
\hline & & \#15 & & \\
\hline \multirow[t]{5}{*}{6} & Misi \#6 & & Sasaran & Tidak disajikan \\
\hline & & & Sacaran & Tidak dicaiikan \\
\hline & & \#17 & & \\
\hline & & & Sasaran & Tidak disajikan \\
\hline & & \#18 & & \\
\hline \multirow[t]{4}{*}{7} & Misi \#7 & $\# 10$ & Sasaran & Tidak disajikan \\
\hline & & & Sasaran & Tidak disaiikan \\
\hline & & \#20 & & \\
\hline & & \#21 & Sasaran & Tidak disajikan \\
\hline
\end{tabular}

Sumber : diolah dari RPJMD Pemkab Buleleng Tahun 2012-2017

Indikator kinerja sasaran merupakan indikator yang akan dicapai oleh Pemerintah Kabupaten Buleleng yang dijabarkan setiap tahunnya melalui Rencana Kirja Pembangunan 
daerah (RKPD) dan Perjanjian Kinerja serta dilaporkan dalam Laporan Akuntabilitas Instansi Pemeritah.

Pengujian indikator kinerja Pemerintah Kabupaten Buleleng dilakukan melalui model logika dengan membandingkan indikator kinerja yang terdapat pada masing-masing dokumen perencanaan dan pertanggungjawaban kinerja. Pengujian model logika dimaksudkan untuk mengetahui alur pikir dan keselarasan antara dokumen kinerja mulai dari perencanaan (RPJMD 2012-2017, RKPD 2015, PK 2015) sampai pada tingkat pengukuran dan pelaporan yang disajikan dalam Laporan Akuntabilitas Kinerja (LAKIP) Pemerintah Kabupaten Buleleng.

Dari analisis melalui model alur pikir (Logic model) ditemukan perbedaan jumlah sasaran dan perbedaan indikator pada dokumen perencanaan dan pelaporan.

\begin{tabular}{|c|c|c|c|c|}
\hline Misi dan Sasaran & RPJMD & RKPD & PK & LAKIP \\
\hline \multicolumn{5}{|l|}{ Misi ke-1 } \\
\hline Sasaran \#1 & 9 & - & & \\
\hline Sasaran \#2 & 6 & - & & \\
\hline Sasaran \#3 & 2 & - & & \\
\hline \multicolumn{5}{|l|}{ Misi \#2 } \\
\hline Sasaran \#4 & 2 & - & & \\
\hline Sasaran \#5 & 2 & - & & \\
\hline Sasaran \#6 & 3 & - & & \\
\hline \multicolumn{5}{|l|}{ Misi \#3 } \\
\hline Sasaran \#7 & 7 & - & & \\
\hline Sasaran \#8 & 5 & - & & \\
\hline Sasaran \#9 & 4 & - & & \\
\hline $\begin{array}{l}\text { Sasaran \#10 } \\
\text { Misi \#4 }\end{array}$ & 2 & - & & \\
\hline Sasaran \#11 & 1 & - & & \\
\hline Sasaran \#12 & 1 & - & & \\
\hline $\begin{array}{l}\text { Sasaran \#13 } \\
\text { Misi \#5 }\end{array}$ & 1 & - & & \\
\hline Sasaran \#14 & 3 & - & & \\
\hline $\begin{array}{l}\text { Sasaran \#15 } \\
\text { Misi \#6 }\end{array}$ & 2 & - & & \\
\hline Sasaran \#16 & 4 & - & & \\
\hline Sasaran \#17 & 5 & - & & \\
\hline $\begin{array}{l}\text { Sasaran \#18 } \\
\text { Misi \#7 }\end{array}$ & 3 & - & & \\
\hline Sasaran \#19 & 3 & - & & \\
\hline Sasaran \#20 & 2 & - & & \\
\hline Sasaran \#21 & 2 & - & & \\
\hline
\end{tabular}

Dalam RPJMD menyajikan sasaran yang akan dicapai oleh pemerintah Kabupaten Buleleng sejumlah 21, namun kemudian dalam Perjanjian Kinerja tahun 2015 jumlah sasaran yang akan dicapai sebanyak 46 sehingga RPJMD tidak selaras dengan PK dan LAKIP. Sasaran yang berubah menyebabkan kesulitan didalam menentukan perbandingan diantara indikator kinerja pada rencana dan eveluasinya. Kebanyakan indikator pada RPJMD kemudian dijadikan sasaran di dalam PK sehingga jumlah sasaran dalam PK menjadi bertambah jauh lebih banyak.

Hal tersebut dapat menunjukkan bahwa kabupaten buleleng telah dapat mencapai lebih banyak sasaran daripada rencana jangka menengahnya, namun yang perlu dipertimbangkan adalah apakah hal tersebut tidak berpengaruh pada keselarasan antara RPJMD dan LAKIP. 


\begin{tabular}{|c|c|c|c|c|}
\hline Misi dan Sasaran & RPJMD & RKPD & PK & LAKIP \\
\hline \multicolumn{5}{|l|}{ Misi ke-1 } \\
\hline Sasaran \#1 & & - & 5 & 5 \\
\hline Sasaran \#2 & & - & 3 & 3 \\
\hline Sasaran \#3 & & - & 3 & 3 \\
\hline Sasaran \#4 & & & 2 & 2 \\
\hline Sasaran \#5 & & & 1 & 1 \\
\hline Sasaran \#6 & & & 2 & 2 \\
\hline \multicolumn{5}{|l|}{ Misi \#2 } \\
\hline Sasaran \#7 & & - & 3 & 3 \\
\hline Sasaran \#8 & & - & 1 & 1 \\
\hline Sasaran \#9 & & - & 2 & 2 \\
\hline Sasaran \#10 & & & 1 & 1 \\
\hline \multicolumn{5}{|l|}{ Misi \#3 } \\
\hline Sasaran \#11 & & - & 1 & 1 \\
\hline Sasaran \#12 & & - & 8 & 8 \\
\hline Sasaran \#13 & & - & 5 & 4 \\
\hline Sasaran \#14 & & - & 2 & 2 \\
\hline Sasaran \#15 & & & 2 & 2 \\
\hline Sasaran \#16 & & & 3 & 3 \\
\hline Sasaran \#17 & & & 3 & 3 \\
\hline Sasaran \#18 & & & 1 & 1 \\
\hline Sasaran \#19 & & & 1 & 1 \\
\hline Sasaran \#20 & & & 2 & 2 \\
\hline Sasaran \#21 & & & 1 & 1 \\
\hline Sasaran \#22 & & & 3 & 3 \\
\hline Sasaran \#23 & & & 2 & 2 \\
\hline Sasaran \#24 & & & 1 & 1 \\
\hline Sasaran \#25 & & & 3 & 3 \\
\hline \multicolumn{5}{|l|}{ Misi \#4 } \\
\hline Sasaran \#26 & & & 1 & 1 \\
\hline Sasaran \#27 & & & 2 & 2 \\
\hline Sasaran \#28 & & - & 2 & 2 \\
\hline Sasaran \#29 & & - & 1 & 1 \\
\hline \multicolumn{5}{|l|}{ Misi \#5 } \\
\hline Sasaran \#30 & & - & 2 & 2 \\
\hline Sasaran \#31 & & - & 2 & 2 \\
\hline \multicolumn{5}{|l|}{ Misi \#6 } \\
\hline Sasaran \#32 & & - & 1 & 1 \\
\hline Sasaran \#33 & & - & 2 & 2 \\
\hline Sasaran \#34 & & - & 5 & 5 \\
\hline Sasaran \#35 & & & 1 & 1 \\
\hline Sasaran \#36 & & & 2 & 2 \\
\hline Sasaran \#37 & & & 2 & 2 \\
\hline Sasaran \#38 & & & 4 & 3 \\
\hline Sasaran \#39 & & & 2 & 1 \\
\hline \multicolumn{5}{|l|}{ Misi \#7 } \\
\hline Sasaran \#40 & & - & 1 & 1 \\
\hline Sasaran \#41 & & - & 2 & 2 \\
\hline Sasaran \#42 & & - & 2 & 2 \\
\hline Sasaran \#43 & & & 3 & 3 \\
\hline Sasaran \#44 & & & 2 & 2 \\
\hline Sasaran \#45 & & & 1 & 1 \\
\hline Sasaran \#46 & & & 5 & 2 \\
\hline
\end{tabular}


Dari perbandingan tabel diatas dapat dilihat bahwa terdapat pengurangan indikator dari perencanaan dan evaluasi, perbedaan tersebut dapat dijabarkan sebagai berikut :

a. Sasaran ke-13 (meningkatnya ketersediaan dan kualitas pendidikan), dengan indikator kinerja :

Siswa tamatan SMK yang bekerja

b. Sasaran ke 38 ( terwujudnya kota layak anak) dengan indikator kinerja :

\% perempuan usia kerja yang berkerja

c. Sasaran ke 39 ( terkendalinya jumlah penduduk )

Rata-rata jumlah anak atau keluarga pasangan usia nikah

d. Sasaran ke 46 (meningkatnya pemanfaatan sumber energy terbarukan)

Rata-rata energy yang yang dihasilkan dari mikro hidro (air)

$\sim$ Rata-rata energy yang dihasilkan dari angin

$\sim$ Rata-rata energy yang dihasilkan dari surya

\subsection{Dukungan Indikator Kinerja SKPD}

Salah satu permasalahan selama ini timbul dalam implementasi sistem akuntabilitas kinerja adalah ketidakselarasan perencanaan antara satu instansi pemerintah dengan instansi pemerintah atasannya bukan dengan perencanaan yang bersifat nasional. Salah satu penyebabnya adalah pengguna indikator kinerja yang tidak selaras sehingga hasil yang disajikan oleh kerja unit tidak selaras dengan instansi pemerintah bahkan hasil/kinerja dari suatu instansi pemerintah tidak selaras dengan apa yang diinginkan perencanaan secara nasional.

Indikator kinerja yang digunakan unit kerja akan lebih spesifik dan rinci namun tetap menjaga keselarasan dan keserasiannya dengan indikator kinerja pada tingkat instansi pemerintah.

Indikator kinerja pada tingkat Pemerintah daerah dan unit kerja/satuan kerja perangkat daerah (SKPD) harus selaras satu dengan lainnya. Bentuk keselaraasannya dapat berupa kesamaan indikator kinerja pada sasaran pemerintah daerah dn unit kerja/ SKPD, dapat berupa indikator kerja sasaran pada unit kerja saling memberi kontribusi atas terpenuhinya indikator kerja pada tingkat pemerintah daerah.

Penelitian ini akan melihat hubungan indikator kerja SKPD terhadap indikator kinerja pemerintah kabupaten Buleleng. Aspek yang akan diteliti meliputi dua aspek, yakni :

1) Keselarasan indikator kinerja perencanaan strategis (Renstra) SKPD terhadap indikator kinerja pemerintah kabupaten Buleleng

2) Keselarasan indikator kinerja outcome program utama yang dilakukan SKPD terhadap indikator Pemerintah Kabupaten Buleleng

Uraian dua aspek penelitian tersebut akan adalah sebagai berikut :

1) Ketidaksamaan Indikator Kinerja RJMD dan Renstra SKD

Untuk dapat mencapai misi dan tujuan pembangunan pemerintah pemerintah Kabupaten Buleleng, sasaran yang telah direncanakan dalam RPJMD 2008-2010 seharusnya dapat didukung oleh Renstra SKD dalam bentuk keselarasan indikator kinerja. Adapun SKD yang dipilih meliputi dua SKPD yang menangani urusan wajib (Dinas Pendidikan Dasar dan Dinas Kesehatan) dan satu SKPD yang menanagani rusan pilihan (Dinas Koperindag)

Rincian indikator kinerja SKPD untuk dinas Pendidikan Dasar, Dinas Kesehatan dan Dinas Koperindag telah diuraikan pada bagian "Sasaran dan Indikator kinerja SKPD" Indikator kinerja sasaran dinas koperindag tidak dicantumkan secara eksplisit dalam dokumen renstra.

Permasalahan keselarasan indikator kinerja sasaran SKPD dengan indikator kinerja sasaran Pemerintah Kabupaten Buleleng adalah sebagai berikut :

1) Sebagian Indikator Kinerja SKPD Tidak Mendukung Indikator Kinerja Pemerintah Kabupaten Buleleng

Penelitian indikator SKpD tersebut dilakukan pada tiga SKPD, yakni dinas pendidikan dasar, dians kesehatan dan dinas koperindag adalah sebagai berikut: 
a. Dinas Pendidkan

Perbandingan dan keselarasan indikator kinerja Pemerintah kabupaten Buleleng dan indikator Dinas Pendidikan.

\begin{tabular}{|c|c|}
\hline $\begin{array}{l}\text { Indikator Kinerja Sasaran Pemerintah } \\
\text { Kabupaten Buleleng }\end{array}$ & $\begin{array}{l}\text { Indikator Kinerja Sasaran Dinas } \\
\text { Pendidikan }\end{array}$ \\
\hline $\begin{array}{l}\text { \%anak usia sekolah yang tuntas wajib } \\
\text { belajar } 9 \text { tahun }\end{array}$ & \\
\hline $\begin{array}{l}\text { APK SD } \\
\text { APK SMP } \\
\text { APK SMA } \\
\text { APK SMK } \\
\text { APM SD } \\
\text { APM SMP } \\
\text { APM SMA } \\
\text { APM SMK }\end{array}$ & $\begin{array}{l}\text { APK SD/Mi/Paket A } \\
\text { APK SMP/Mts/Paket B } \\
\text { APK SMA/MA/SMK/Paket C }\end{array}$ \\
\hline $\begin{array}{l}\text { Rata-rata nilai UN ,UAS BN } \\
\text { Peningkatan angka kelulusan } \\
\text { Peningkatan angka kenaikan kelas } \\
\text { Siswa tamatan smp yang melanjutkan } \\
\text { Siswa tamatan SMK yang bekerja }\end{array}$ & \\
\hline $\begin{array}{cc}\text { Rasio ruangan } & \text { SMA/SMK/MA } \\
\text { terhadap murid } & \end{array}$ & $\begin{array}{l}\text { RUANG KELAS RUSAK } \\
\% \text { SD Memiliki Perpustakaan } \\
\% \text { SD Memiliki Lab Komputer } \\
\% \text { SMP Memiliki Perpustakaan } \\
\% \text { SMP Memiliki Lab Komputer } \\
\% \text { SMP Memiliki Lab IPA } \\
\% \text { SMA Memiliki Perpustakaan } \\
\% \text { sma Memiliki Lab Komputer } \\
\% \text { SMA Memiliki Lab IPA }\end{array}$ \\
\hline Rasio guru terhadap murid & $\begin{array}{l}\text { \% Guru TK Kualifikasi S1/D4 } \\
\% \text { Guru TK Bersertifikasi } \\
\text { Rasio Guru SD terhadap Siswa } \\
\% \text { Guru SD S1/D4 } \\
\text { \% Guru SD Bersertifikasi } \\
\text { Rasio Guru SMP terhadap Siswa } \\
\% \text { Guru Berkualifikasi S1/D4 } \\
\% \text { Guru SMP Bersertifikasi } \\
\text { Rasio Guru SMA terhadap Siswa } \\
\% \text { Guru SMA S1/D4 } \\
\text { Guru SMA Bersertifikasi } \\
\text { Rasio Guru SMK terhadap Siswa } \\
\% \text { Guru SMK S1/D4 } \\
\text { \% Guru SMK Bersertifikasi }\end{array}$ \\
\hline $\begin{array}{l}\% \text { penurunan angka buta huruf } \\
\% \text { penurunan angka putus sekolah }\end{array}$ & \\
\hline $\begin{array}{l}\text { Rasio ketersediaan SD/MI terhadap } \\
\text { murid } \\
\text { Rasio ketersediaan SMP/MTs } \\
\text { terhadap murid } \\
\text { Rasio ketersediaan SMA/SMK/MA } \\
\text { terhadap murid }\end{array}$ & \\
\hline
\end{tabular}


peningkatan perolehan emas

peningkatan perolehan perak

peningkatan perolehan perunggu

Indikator kinerja pemerintah kabupaten buleleng yang berkenaan dengan aspek pendidikan terdapat dalam misi ketiga sasaran \#11-\#17. Tabel diatas menunjukkan bahwa indikator kinerja Pemerintah Kabupaten Buleleng belum selaras dengan indikator kinerja Dinas Pendidikan. Perbedaan tersebut dapat disebabkan oleh tiga kemungkinan, yaitu :

1) Belum teradopsinya indikator kinerja utama dinas pendidikan ke dalam indikator kinerja pemerintah kabupaten buleleng

2) Indikator kinerja pemerintah kabupaten belum diserap atau dijabarkan dalam indikator kinerja dinas pendidikan

3) Belum ada indikator kinerja Pemerintah Kabupaten Buleleng dan indikator kinerja Dinas Pendidikan yang tepat dan saling mendukung.

b. Dinas kesehatan

\begin{tabular}{|c|c|}
\hline $\begin{array}{ccc}\text { Indikator } & \text { Kinerja } & \text { Sasaran } \\
\text { Pemerintah Kabupaten Buleleng } & \end{array}$ & $\begin{array}{l}\text { Indikator Kinerja Sasaran Dinas } \\
\text { Kesehatan }\end{array}$ \\
\hline $\begin{array}{l}\text { Meningkatnya a a ksesibilitas } \\
\text { peemertaan keterjangkauan dan } \\
\text { pelayanan kesehatan bagi masyarakat }\end{array}$ & \\
\hline Meningkatnya usia harapan hidup & $\begin{array}{l}\text { Meningkatnya usia harapan hidup } \\
\text { Menurunnya angka kematian ibu } \\
\text { Menurunnya angka kematian bayi } \\
\text { Menurunnya angka balita yang } \\
\text { pendek(stunting) menjadi dibawah } 32 \% \\
\text { Menurunnya prevalensi gizi kurang } \\
\text { menjadi dibawah } 15 \% \\
100 \% \text { gizi buruk mendapat perawatan } \\
80 \% \text { bayi } 0-6 \text { bulan mendapat ASI } \\
\text { eksclusif } \\
100 \% \text { anak } 6-24 \text { bulan gakin } \\
\text { mendapat MP ASI } \\
\text { Menurunnya prevalensi gizi kurang } \\
\text { pada ibu hamil } \\
95 \% \text { ibu hamil mendapat } 90 \text { tablet } \\
\text { besi } \\
95 \% \text { balita ditimbang berat } \\
\text { badaannya } \\
100 \% \text { gizi buruk mendapat perawatan } \\
90 \% \text { rumah tangga mengonkonsumsi } \\
\text { garam beryodium } \\
95 \% \text { balita usia } 6-54 \text { bulan mendapat } \\
\text { kapsul vitamin }\end{array}$ \\
\hline \multicolumn{2}{|l|}{$\begin{array}{l}\text { Meningkatnya ketersediaan tenaga } \\
\text { medis dan para medis }\end{array}$} \\
\hline $\begin{array}{l}\text { Menurunnya serangan penyakit } \\
\text { menular }\end{array}$ & $\begin{array}{l}\text { Menurunnya angka kesakitan akibat } \\
\text { penyakit menular }\end{array}$ \\
\hline \multicolumn{2}{|l|}{$\begin{array}{l}\text { Meningkatnya pelayanan prima di } \\
\text { RSUD }\end{array}$} \\
\hline & $\begin{array}{c}\text { Jumlah lansia yang memperoleh } \\
\text { pelayanan kesehatan }\end{array}$ \\
\hline
\end{tabular}




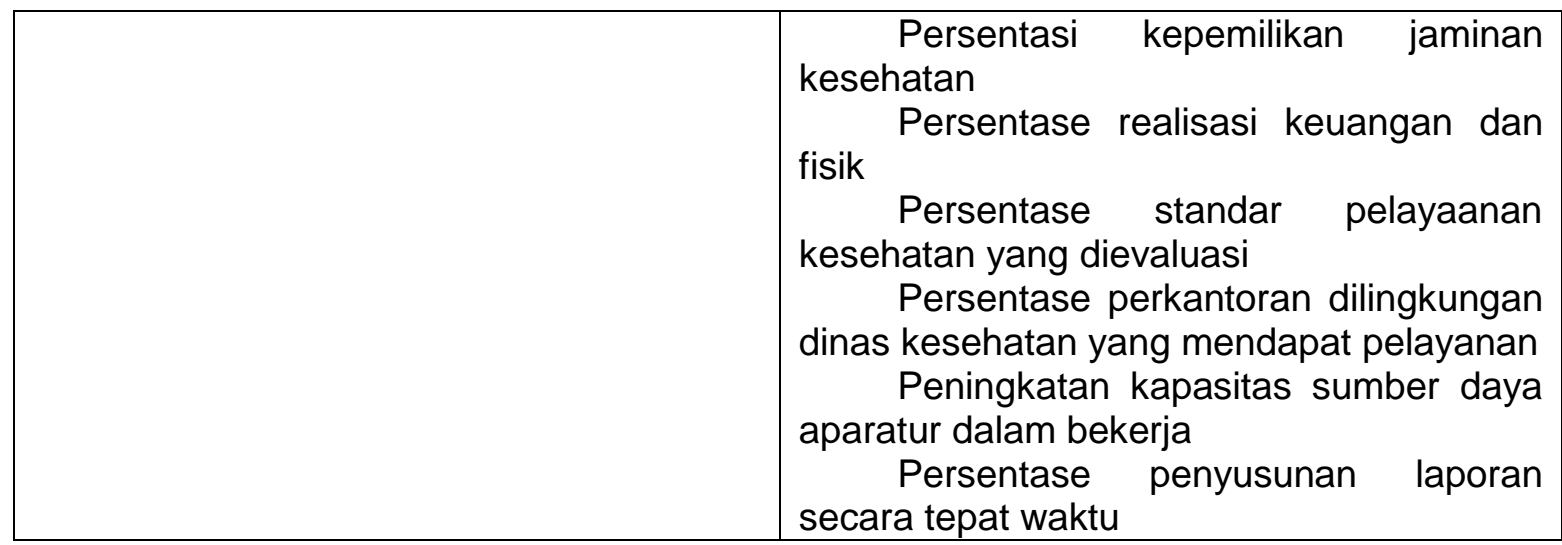

c. Dinas Koperindag

\begin{tabular}{|c|c|}
\hline $\begin{array}{ccc}\text { Indikator } & \text { Kinerja } & \text { Sasaran } \\
\text { Pemerintah Kabupaten Buleleng } & \\
\end{array}$ & $\begin{array}{l}\text { Indikator Kinerja Sasaran Dinas } \\
\text { Kesehatan }\end{array}$ \\
\hline $\begin{array}{l}\text { \%jumlah koperasi yang sehat } \\
\text { \% UMKM yang berkembang } \\
\text { Jumlah UMKM yang meningkat } \\
\text { statusnya }\end{array}$ & $\begin{array}{l}\text { Persentase penilaian kesehatan } \\
\text { Koperasi } \\
\text { Persentase UMKM yang } \\
\text { Berkembang } \\
\text { Jumlah UMKMyangMeningkat } \\
\text { Statusnya }\end{array}$ \\
\hline$\%$ pertumbuhan IKRT & Persentase Pertumbuhan IKRT \\
\hline $\begin{array}{c}\% \text { pengaduan } \\
\begin{array}{c}\text { konsumen } \\
\text { ditindak lanjuti }\end{array}\end{array}$ & $\begin{array}{l}\text { Persentase Pengaduan Konsumen } \\
\text { yang ditindaklanjuti }\end{array}$ \\
\hline $\begin{array}{l}\text { Indeks Kepuasan Konsumen } \\
\% \text { peningkatan } \mathrm{PAD}\end{array}$ & Indeks Kepuasan Konsumen \\
\hline- & $\begin{array}{l}\text { Jumlah dokumen anggaran SKPD } \\
\text { Jumlah } \quad \text { program } \\
\text { administrasi }\end{array}$ \\
\hline- & $\begin{array}{l}\text { Jumlah pegawai yang mengikuti } \\
\text { bimtek / seminar lokakarya }\end{array}$ \\
\hline- & $\begin{array}{l}\text { Persentase koperasi aktif } \\
\text { Pembubaran Koperasi tidak aktif } \\
\text { Persentase penilaian kesehatan } \\
\text { Koperasi } \\
\text { Jumlah penerbitan legalitas UMKM } \\
\text { dan koperasi } \\
\text { Peningkatan volume usaha koperasi } \\
\text { Peningkatan volume produksi industri }\end{array}$ \\
\hline- & $\begin{array}{l}\text { Jumlah jenis distribusi barang yang } \\
\text { dalam pengawasan } \\
\text { Persentase rata-rata kenaikan harga } \\
9 \text { bahan pokok } \\
\text { Jumlah Temuan Barang Kadaluarsa } \\
\text { Persentase Pengaduan Konsumen } \\
\text { yang ditindaklanjuti } \\
\text { Jumlah alat ukur dan timbangan yang } \\
\text { sesuai standart } \\
\text { Jumlah pasar yang kondisi baik }\end{array}$ \\
\hline
\end{tabular}

Indikator kinerja pada Pemerintah Kabupaten Buleleng sudah tercermin dalam renstra dinas koperindag, namun ada beberapa indikator yang bertambah yang dimungkinkan untuk mendukung indikator kinerja yang lain. 


\section{Simpulan dan Saran}

Penelitian ini merupakan evaluasi yang menilai proses penyusunan indikator kinerja pada Pemerintah Kabupaten Buleleng dengan melakukan analisis atas indikator kinerja pada dokumen perencanaan hingga dokumen pengukuran dan pelaporan kinerja

Dapat ditarik kesimpulan terhadap hasil evaluasi penyusunan indikator kinerja Pemerintah Kbaupaten Buleleng, sebagai berikut :

1. Indikator kinerja Pemerintah Kabupaten Buleleng belum menunjukan kesesuaian informasi mulai dari dokumen perencanaan hingga dokumen pelaporan masih banyak terdapat hal yang berbeda bahkan sulit untuk dibandingkan.

2. Indikator kinerja SKPD /unit kerja belum sepenuhnya mendukung kinerja Pemerintah Kabupaten Buleleng. Hal ini ditunjukan dengan masih ditemukannya ketidakselarasan antara indikator kinerja SKPD dengan indikator kinerja sasaran Pemerintah Kabupaten Buleleng.

Berdasarkan simpulan di atas, maka saran yang dapat diberikan pada penelitian mengenai indikator kinerja Pemerintah Buleleng yang kami paparkan kami mengharapkan utamanya pemerintah dalam keterbukan mengenai informasi yang menjadi sumber keputusan dan informasi yang nantinya bisa dijadikan bahan dalam penentuan dan perbandingan dengan kinerja pada pemerintahan di daerah lain ehingga banyak pihak yang mendapatkan data sebagai inforasi dalam penunjang aktivitas yang terkait hal tersebut.

Selain itu juga ini juga bagian dari sikap keterbukaan oleh pemerintah kepada masyarakat umum dimana banyak hal yang menjadi pertanyaan nantinya akan terjawab apabila pemerintah dengan sigap memberikan respon dengan dikeluarkannya ataupun diberikan kesempatan kepada pihak bersangkutan dalam memenuhi datanya yang menjadi acuan nantinya dalam penyusunan laporan mengenai pemerintahan terkait indicator kinerjanya.

Pemberian informasi mengenai indicator kinerja Pemerintah itu sebenarnya bukanlah hal yang illegal jika dipublikasikan berdasarkan proses yang tepat dan penyuntingan informasi sesuai dengan realita dan dibawah pertanggungan pihak tertentu yang menjadi penanggung jawab, proses yang tepat akan melahirkan hasil tepat juga dengan didukung oleh pihak yang terbuka dan jujur dalam memberikan segala yang dibutuhkan selama tidak merugikan perusahaan itu sendiri.

Hal yang menjadi pertanyaan adalah bagaimana nantinya jika masyarakat mendapat informasi yang salah, tentunya akan menciptakan situasi abu-abu (ambiguous situation) sebagai awal dalam penyususnan laporan mengenai kinerja pemerintahan maka diharapkan tidak menimbulkan kesalah pahaman dan nantinya merambat pada kinerja lainnya.

\section{Daftar Pustaka}

Mardiasmo.2009. Akuntansi Sektor Pubik. Yogyakarta : Andi.

Marvin,Henry.2010. Evaluasi Penyusunan Indikator Kinerja Pada Pemerintah Kabupaten Bantul. Yogyakarta.

Rencana Pembangunan Jangka Menengah Daerah Kabupaten Buleleng tahun 2012-2017

RKPD Kabupaten Buleleng

LAKIP Kabupaten Buleleng

Penetapan Kinerja Kabupaten Buleleng tahun 2015

Rencana Strategis SKPD di Kabupaten Buleleng tahun 2012-2017 